\title{
DNA Replication Licensing Factor MCM2
}

National Cancer Institute

\section{Source}

National Cancer Institute. DNA Replication Licensing Factor MCM2. NCI Thesaurus. Code C28642.

DNA replication licensing factor MCM2 (904 aa, 102 kDa) is encoded by the human MCM2 gene. This protein plays a role in cell cycle regulation. 